\title{
PERJANJIAN-PERJANJIAN PEKERJAAN DUA NEGARA (INDONESIA- MALAYSIA) DILIHAT DARI SEJARAH, POLITIK DAN PEMERINTAHAN (INDONESIA-MALAYSIA)
}

Oleh:

\author{
ANITA MARIANATA \\ Dosen Prodi Administrasi Publik Fakultas Ilmu-Ilmu Sosial UNIVED Bengkulu
}

\begin{abstract}
Basically, to state an employment agreement is considered valid or not it's obliged to pay attention to the provisions of article 1320 of the Civil Code. The provisions of the employment agreement at least benefit workers as stipulated in the labor legislation, company regulations, or collective agreements. A revised agreement between the governments of Malaysia and Indonesia provide some benefits for migrant domestic workers but failed to provide some degree of protection related to low wages and high cost of recruitment. A series of violent cases received widespread attention led Indonesia in June 2009 to prohibit new recruitment of domestic workers to work in Malaysia until the new protection is applied. This agreement includes a positive change where workers are allowed to keep their passports instead must submit passports to the employer, and ensure workers to get their weekly rest. But the agreement didn't stipulate a minimum wage as Indonesia wanted and perpetuates the recruitment fee structures that entrap workers in debt.
\end{abstract}

\section{Keywords: Employment Agreement, History, Politics, Government}

\section{PENDAHULUAN}

Salah satu tujuan negara Republik Indonesia sebagaimana tercantum dalam Pembukaan UUD 1945 adalah ikut melaksanakan ketertiban dunia yang berdasarkan kemerdekaan, perdamaian abadi, dan keadilan sosial. Ketertiban dunia hanya mungkin terwujud jika setiap negara hidup berdampingan secara damai. Apabila setiap negara tidak berkeinginan untuk menyerang negara lain, melanggar hak asasi manusia, atau bertindak sewenang-wenang, maka perdamaian dunia akan terwujud. Hidup berdampingan dengan bangsa-bangsa lain secara damai merupakan dambaan bagi setiap bangsa yang beradab di dunia.

Secara fisik maupun psikis (kejiwaan), hati nurani manusia sangat merindukan rasa damai, aman, tertib dan tenteram dalam suasana perikeadilan dan perikemanusiaan. Dalam rangka menciptakan perdamaian dunia yang abadi, adil dan sejahtera, negara kita harus tetap melaksanakan politik luar negeri yang bebas dan aktif. Dengan melakukan kerjasama internasional maka akan lebih menjamin persahabatan antar bangsa. Manfaat yang dapat diperoleh dan kerjasama antarbangsa di antaranya adalah sebagai berikut:

a. Bidang Ideologi, akan saling menghormati meskipun terjadi perbedaan landasan/falsafah negara.

b. Bidang Politik, sama-sama berorientasi path kepentingan nasional.

c. Bidang Ekonomi, adanya kerjasama yang saling menguntungkan untuk meningkatkan kesejahteraan, terjadinya hubungan perdagangan eksport import.

d. Bidang Sosial Budaya, saling melengkapi namun tetap berpedoman pada kepribadian bangsa masingmasing. 
e. Bidang Pertahanan dan Keamanan, adanya latihan perang bersama untuk meningkatkan kemampuan pertahanan dan keamanan.

Bangsa Indonesia menjalin hubungan internasional atau hubungan antarbangsa. Indonesia melaksanakan kebijaksanaan tersebut dalam wujud hubungan luar negeri. Pelaksanaan hubungan luar negeri oleh bangsa Indonesia didasarkan pada asas kesamaan derajat, saling menghormati, saling menguntungkan dan tidak saling mencampuri urusan dalam negeri masingmasing.

Bentuk-bentuk kerja sama dan perjanjian Indonesia dengan negara lain keikutsertaan Indonesia dalam hubungan internasional merupakan perwujudan salah satu tujuan nasional yaitu melaksanakan ketertiban dunia yang berdasarkan kemerdekaan, perdamaian abadi, dan keadilan sosial. Keikutsertaan tersebut dinyatakan dengan membentuk organisasi internasional, di mana Indonesia sebagai anggotanya memprakarsai pembentukan kerjasama internasional dan rnenjadi anggota suatu organisasi internasional. Keterlibatan Indonesia dalam hubungan internasional terjadi, baik dalam bentuk organisasi internasional maupun kerjasama internasional, antara lain: Konferensi Asia Afrika (KAA), Gerakan Non B I ok (GNB), ASEAN (Association of South East Asian Nations), Perserikatan Bangsa Bangsa (PBB), OPEC (Organization of Petroleum Exporting Countries), APEC (Asia Pasific Economi Cooperation), OKI (Organisasi Konferensi Islam), dan sebagainya.

Untuk meningkatkan kerjasama internasional perlu dikembangkan sikapsikap positif, antara lain sebagai berikut: pertama, adanya kemampuan dan kesiapan diri) untuk memperkenalkan kebudayaan nasional, pertukaran pemuda, pelajar dan mahasiswa serta kegiatan olah raga. Kedua, mengikuti perkembangan dunia dengan cermat, sehingga dapat mengambil langkah-langkah nyata. Ketiga, secara dini apabila terjadi masalah yang dapat mengganggu stabilitas nasional. Keempat, mewujudkan tata ekonomi yang tidak dapat mengganggu stabilitas nasional. Kelima, kesiapan dan kemampuan diri untuk menciptakan perdamaian abadi dan keadilan sosial.

$$
\text { Hasil-hasil kerjasama dan }
$$

perjanjian internasional yang bermanfaat bagi Indonesia bagi Indonesia, kerjasama internasional mempunyai arti untuk mewujudkan dunia yang tertib damai, dapat menjalani kehidupan yang selaras dengan semua bangsa dan membina kerjasama di segala bidang demi kesejahteraan bersama. Berangkat dari permasalahan di atas, artikel ini bertujuan untuk untuk mengetahui seperti apa perjanjian-perjanjian pekerjaan antara Indonesia dan Malaysia dilihat dari sejarah, politik, dan pemerintahan Indonesia dan Malaysia, dan untuk untuk memahami pentingnya menjalin hubungan yang baik dan positif antar kedua negara.

\section{Konsep Perjanjian Pekerjaan}

Kerja merupakan bentuk kegiatan yang dilakukan untuk mencapai suatu penghidupan yang layak. Pekerjaan sangat berarti dalam upaya kelangsungan hidup dan mengaktualisasi diri sehingga dapat lebih bermakna dan dihargai dalam lingkungan sekitarnya. Hak bagi setiap orang, baik laki-laki maupun perempuan untuk memperoleh pekerjaan. Sehingga pekerjaan mempunyai makna yang sangat berarti dalam kehidupan manusia. Hal ini merupakan salah satu bentuk hak yang melekat didalam diri bangsa Indonesia, sebagaimana yang diamanatkan UndangUndang Dasar (UUD) 1945. Perubahan IV UUD 1945 Pasal 27 ayat (1) menyatakan "setiap warga negara berhak atas pekerjaan dan penghidupan yang layak bagi kemanusian”. Ketentuan ini diperkuat dengan pasal 28 D ayat (2) menyatakan "setiap orang berhak untuk bekerja serta mendapat imbalan dan pelakuan yang adil dan layak dalam hubungan kerja”. 
Oleh karena hal ini diatur dalam Undang-Undang Dasar, pemerintah sebagai penyelenggara pembangunan berkewajiban untuk memfasilitasi setiap warga negaranya agar dapat berkerja dalam rangka meningkatkan kesejahteraan diri dan keluarganya, dan harus dilakukan seoptimal mungkin oleh negara. Dengan demikian, hak setiap warga negara dalam memperoleh pekerjaan dapat terpenuhi. Pemerintah berperan penting dalam mengatur mengenai pekerjaan terutama dalam hal perjanjian kerja.

Perumusan mengenai perjanjian diatur dalam Pasal 1313 KUH Perdata yang menyebutkan:

"suatu perjanjian adalah suatu perbuatan dengan mana satu orang atau lebih mengikatkan dirinya terhadap satu orang lain atau lebih”.

Menurut Subekti (2002: 1) menyebutkan bahwa suatu perjanjian sebagai suatu peristiwa dimana seseorang berjanji kepada seorang lain atau dimana dua orang itu saling berjanji untuk melaksanakan suatu hal. Perjanjian juga dinamakan sebagai persetujuan (overeenkomst), karena kedua belah pihak setuju untuk melakukan suatu hal. Maka kedua kata yakni perjanjian dan persetujuan mempunyai pengertian yang sama. Bisa disimpulkan bahwa perjanjian merupakan suatu hal yang konkrit atau suatu peristiwa.

Definisi perjanjian kerja menurut Pasal 1 angka 14 Undang-Undang Nomor 13 Tahun 2003 tentang Ketenagakerjaan adalah perjanjian antara pekerja/buruh dengan pengusaha atau pemberi kerja yang memuat syarat-syarat kerja, hak dan kewajiban para pihak. Dari definisi tersebut dapat disimpulkan bahwa perjanjian kerja harus dipatuhi dan dilaksanakan oleh para pihak yang membuatnya. Namun, perjanjian kerja pun dapat diakhiri bilamana:

1. pekerja meninggal dunia;

2. berakhirnya jangka waktu perjanjian kerja;
3. adanya putusan pengadilan dan/atau putusan atau penetapan lembaga penyelesaian perselisihan hubungan industrial yang telah mempunyai kekuatan hukum tetap; atau

4. adanya keadaan atau kejadian tertentu yang dicantumkan dalam perjanjian kerja, peraturan perusahaan, atau perjanjian kerja bersama yang dapat menyebabkan berakhirnya hubungan kerja.

Berakhirnya perjanjian kerja sebagaimana tersebut di atas diatur dalam Pasal 61 ayat (1) UU Ketenagakerjaan.

\section{Hukum Perjanjian dan Pelaksanaan Perjanjian}

Dalam hukum perjanjian terdapat beberapa asas atau prinsip yang harus diperhatikan bagi para pihak. Hal ini penting untuk menjadi pegangan dalam proses dan pelaksanaan perjanjian serta jika terdapat permasalahan hukum yang berkaitan proses dan pelaksanaan perjanjian tersebut.

Hukum perjanjian menganut sistem terbuka, yang berarti memberikan kebebasan seluas-luasnya kepada masyarakat untuk mengadakan perjanjian yang berisi apa saja, asalkan tidak melanggar ketertiban umum dan kesusilaan. Sistem terbuka mengandung suatu asas kebebasan membuat perjanjian. Hal tersebut dapat disimpulkan dari Pasal 1338 ayat (1) KUH Perdata, yaitu sebuah perjanjian yang dibuat secara sah berlaku sebagai undang-undang bagi mereka yang membuatnya.

Permasalahan yang terdapat dalam pelaksanaan perjanjian adalah apabila debitur tidak memenuhi janjinya kepada kreditur. Apabila kreditur yang diberi kuasa oleh hakim untuk mewujudkan sendiri apa yang menjadi haknya menurut perjanjian, maka dapat dikatakan bahwa perjanjian tersebut dapat dieksekusi secara riil. 


\section{METODOLOGI PENELITIAN}

Metode penelitian bermakna sempit maupun luas. Dalam artian sempit, metode penelitian berhubungan dengan rancangan penelitian dan prosedur-prosedur pengumpulan data serta analisis data. Menurut Ida Bagoes Mantra dalam bukunya "Filsafat Penelitian \& Metode Penelitian Sosial" menyebutkan bahwa penelitian deskriptif bertujuan untuk mendeskripsikan atau melukiskan realitas sosial yang kompleks yang lahir dalam masyarakat (Mantra, 2004:38) sedangkan Analisis adalah sebuah metode yang digunakan dengan cara menganalisis isi dari beberapa materi tertulis (Mantra, 2004:89).

Sehingga metode penelitian yang digunakan penulis dalam penelitian ini adalah metode penelitian DeskriptifAnalisis, yaitu mendeskripsikan tentang perjanjian-perjanjian pekerjaan yang dibuat oleh pemerintah Indonesia dan Malaysia.

\section{Teknik Pengumpulan Data}

Penulis menggunakan teknik pengumpulan data studi kepustakaan (library research), dengan mengumpulkan data dan dokumen resmi yang dikeluarkan oleh pemerintah, buku-buku teks, makalah, jurnal, dan dokumen yang berhubungan dengan masalah penelitian, sehingga mendapatkan data-data tertulis yang dapat didokumentasikan.

\section{Gambaran Umum}

\section{A. Sejarah, Politik, dan Pemerintahan Indonesia}

Pada tanggal 23 Agustus sampai dengan 2 September 1949 dikota Den Hagg, (Belanda) diadakan konferensi Meja Bundar (KMB). Delegasi RI dipimpin oleh Drs. Moh. Hatta, delegasi BFO (Bijeenkomst voor Federale Overleg) dipimpin oleh Sultan Hamid Alkadrie dan delegasi Belanda dipimpin olah Van Harseveen. Adapun tujuan diadakannya KMB adalah untuk meyelesaikan persengketaan Indonesia dan Belanda secepatnya dengan cara yang adil dan pengakuan kedaulatan yang nyata, penuh dan tanpa syarat kepada Republik Indonesia Serikat (RIS).

Salah satu keputusan pokok KMB yaitu kerajaan Balanda mengakui kedaulatan Indonesia sepenuhnya tanpa syarat dan tidak dapat dicabut kembali kepada RIS selambat-lambatnya pada tanggal 30 Desember 1949. Demikianlah pada tanggal 27 Desember 1949 Ratu Juliana menandatangani Piagam Pengakuan Kedaulatan RIS di Amesterdam.

UUDS 1950 adalah konstitusi yang berlaku di negara Republik Indonesia sejak 17 Agustus 1950 hingga dikeluarkannya Dekrit Presiden 5 Juli 1959. UUDS 1950 ditetapkan berdasarkan Undang-Undang Nomor 7 Tahun 1950 tentang Perubahan Konstitusi Sementara Republik Indonesia Serikat menjadi Undang-Undang Dasar Sementara Republik Indonesia, dalam Sidang Pertama Babak ke-3 Rapat ke-71 DPR RIS tanggal 14 Agustus 1950 di Jakarta. Konstitusi ini dinamakan "sementara", karena hanya bersifat sementara, menunggu terpilihnya Konstituante hasil pemilihan umum yang akan menyusun konstitusi baru. Pemilihan Umum 1955 berhasil memilih Konstituante secara demokratis, namun Konstituante gagal membentuk konstitusi baru hingga berlarut-larut.

Dekrit Presiden 1959

dilatarbelakangi oleh kegagalan Badan Konstituante untuk menetapkan UUD baru sebagai pengganti UUDS 1950. Anggota konstituante mulai bersidang pada 10 November 1956. Namun pada kenyataannya sampai tahun 1958 belum berhasil merumuskan UUD yang diharapkan. Sementara, di kalangan masyarakat, pendapat-pendapat untuk kembali kepada UUD '45 semakin kuat. Dalam menanggapi hal itu, Presiden Soekarno lantas menyampaikan amanat di depan sidang Konstituante pada 22 April 1959 yang isinya menganjurkan untuk kembali ke UUD '45. Pada 30 Mei 1959 
Konstituante melaksanakan pemungutan suara. Hasilnya 269 suara menyetujui UUD 1945 dan 199 suara tidak setuju. Meskipun yang menyatakan setuju lebih banyak tetapi pemungutan suara ini harus diulang, karena jumlah suara tidak memenuhi kuorum. Pemungutan suara kembali dilakukan pada tanggal 1 dan 2 Juni 1959. Dari pemungutan suara ini, Konstituante juga gagal mencapai kuorum. Untuk meredam kemacetan, Konstituante memutuskan reses yang ternyata merupkan akhir dari upaya penyusunan UUD. Pada 5 Juli 1959 pukul 17.00 Presiden Soekarno mengeluarkan dekrit yang diumumkan dalam upacara resmi di Istana Merdeka. Karena situasi politik pada Sidang Konstituante 1959 dimana banyak saling tarik ulur kepentingan partai politik sehingga gagal menghasilkan UUD baru, maka pada tanggal 5 Juli 1959, Presiden Sukarno mengeluarkan Dekrit Presiden yang salah satu isinya memberlakukan kembali UUD 1945 sebagai undangundang dasar, menggantikan UndangUndang Dasar Sementara 1950 yang berlaku pada waktu itu.

Pada masa Orde Baru (1966-1998), Pemerintah menyatakan akan menjalankan UUD 1945 dan Pancasila secara murni dan konsekuen. Namun pelaksanaannya ternyata menyimpang dari Pancasila dan UUD 1945 yang murni, terutama pelanggaran pasal 23 dan pasal 33 UUD 1945 yang memberi kekuasaan pada pihak swasta untuk menghancurkan hutan dan sumber daya alam.

Salah satu tuntutan Reformasi 1998 adalah dilakukannya perubahan (amandemen) terhadap UUD 1945. Latar belakang tuntutan perubahan UUD 1945 antara lain karena pada masa Orde Baru, kekuasaan tertinggi di tangan MPR (Majelis Permusyawaratan Rakyat), kekuasaan yang sangat besar pada Presiden, adanya pasal-pasal menimbulkan multitafsir, serta kenyataan rumusan UUD 1945 tentang semangat penyelenggara negara yang belum cukup didukung ketentuan konstitusi.
Tujuan perubahan UUD 1945 waktu itu adalah menyempurnakan aturan dasar seperti tatanan negara, kedaulatan rakyat, HAM, pembagian kekuasaan, eksistensi negara demokrasi dan negara hukum, serta hal-hal lain yang sesuai dengan perkembangan aspirasi dan kebutuhan bangsa. Perubahan UUD 1945 dengan kesepakatan diantaranya tidak mengubah Pembukaan UUD 1945, tetap mempertahankan susunan kenegaraan (staat structuur) kesatuan atau selanjutnya lebih dikenal sebagai Negara Kesatuan Republik Indonesia (NKRI), serta mempertegas sistem pemerintahan presidensiil.

\section{B. Sejarah, Politik, dan Pemerintahan Malaysia}

Malaysia adalah sebuah negara federasi yang terdiri dari tiga belas negara bagian dan tiga wilayah persekutuan di Asia Tenggara dengan luas 329.847 km persegi. Ibukotanya adalah Kuala Lumpur, sedangkan Putrajaya menjadi pusat pemerintahan persekutuan. Jumlah penduduk negara ini melebihi 27 juta jiwa. Kepala negara Malaysia adalah Yang diPertuan Agong dan pemerintahannya dikepalai oleh seorang Perdana Menteri. Model pemerintahan Malaysia miripdengan sistem parlementer Westminster.

Malaysia sebagai negara persekutuan tidak pernah ada sampai tahun 1963. Sebelumnya, sekumpulan koloni didirikan oleh Britania Raya pada akhir abad ke-18, dan paro barat Malaysia modern terdiri dari beberapa kerajaan yang terpisah-pisah. Kumpulan wilayah jajahan itu dikenal sebagai Malaya Britania hingga pembubarannya pada 1946, ketika kumpulan itu disusun kembali sebagai Uni Malaya. Karena semakin meluasnya tentangan, kumpulan itu lagi-lagi disusun kembali sebagai Federasi Malaya pada tahun 1948 dan kemudian meraih kemerdekaan pada 31 Agustus1957.

Bangsa-bangsa di Asia Tenggara mengalami ledakan ekonomi dan 
menjalani perkembangan yang cepat di penghujung abad ke-20. Pertumbuhan yang cepat pada dasawarsa 1980-an dan 1990-an, rata-rata 8\% dari tahun 1991 hingga 1997, telah mengubah Malaysia menjadi negara industri baru. Karena Malaysia adalah salah satu dari tiga negara yang menguasai Selat Malaka, perdagangan internasional berperan penting di dalam ekonominya. Pada suatu ketika, Malaysia pernah menjadi penghasil timah, karet, dan minyak kelapa sawit di dunia. Industri manufaktur memiliki pengaruh besar bagi ekonomi negara ini. Malaysia juga dipandang sebagai salah satu dari 18 negara berkeanekaragaman hayati terbesar di dunia.

Suku Melayu menjadi bagian terbesar dari populasi Malaysia. Terdapat pula komunitas TionghoaMalaysia dan India-Malaysia yang cukup besar. Bahasa Melayu dan Islam masingmasing menjadi bahasa dan agama resmi negara. Malaysia adalah anggota perintis ASEAN dan turut serta di berbagai organisasi internasional, seperti PBB. Sebagai bekas jajahan Inggris, Malaysia juga menjadi anggota Negara-Negara Persemakmuran.

\section{PEMBAHASAN DAN HASIL PENELITIAN \\ Pembahasan}

Perjanjian internasional Indonesia merupakan salah satu bukti mutualisme yang dilakukan Indonesia dengan negara lain. Dalam ikatan hubungan antar bangsa, perjanjian internasional tidak bisa dipandang sebelah mata. Dengan adanya perjanjian internasional, maka hubungan negara-negara yang tercantum dalam perjanjian tersebut akan diikat oleh hukum internasional demi mencapai suatu kepastian yang sah. Seperti yang termaktub dalam perjanjian internasional Indonesia yang selama ini diratifikasi oleh pemerintah Indonesia, di dalamnya diatur hal-hal yang menyangkut hak dan kewajiban antara subyek-subyek hukum internasional atau antarnegara. Dalam membuat suatu perjanjian yang terpenting adanya kesadaran masing-masing pihak yang tercantum dalam perjanjian untuk mematuhinya baik secara etis maupun normatif.

Sebelum terbentuknya suatu perjanjian internasional yang mengikat antara suatu negara dengan negara lainnya, dibutuhkan tahap-tahap sebagai berikut:

- Perundingan (negotiation). Pada tahap awal dilakukan perundingan antara pihak/negara tentang objek tertentu. Dalam tahap pelaksanaan negosiasi, suatu negara dapat diwakili oleh pejabat yang dapat menunjukkan surat kuasa penuh (full powers) dari pemerintah negaranya. Dalam hal ini juga dapat dilakukan oleh kepala negara, kepala pemerintahan, menteri luar negeri, atau duta besar. Perundingan yang dilakukan dalam rangka perjanjian bilateral disebut talk. Sedangkan dalam rangka multilateral diplomatic conference atau konferensi. Selain secara resmi juga ada perundingan yang tidak resmi. Perundingan tidak resmi tersebut sering dinamakan comdor talk.

- Penandatanganan (signature). Setelah perundingan membuahkan kesepakatan bersama, maka dilanjutkan dalam tahap kedua yaitu penandatanganan hasil perundingan yang dituangkan dalam naskah perundingan dan dilakukan wakil-wakil negara peserta yang hadir. Dalam perjanjian bilateral dilakukan penandatanganan dilakukan oleh kedua wakil negara yang telah melakukan perundingan sehingga penerimaan hasil perundingan secara penuh dan mutlak sangat diperlukan oleh kedua belah pihak.

- Pengesahan (ratification). Pengesahan merupakan tahap akhir sekaligus final dari proses 
pembuatan perjanjian internasional. Proses pengesahan dilakukan dimana suatu negara menggabungkan diri pada sebuah perjanjian yang salah satu syaratnya adalah perjanjian tersebut telah berstatus sah, yang disetujui oleh badan berwenang yang ada di negara bersangkutan. Penandatanganan perjanjian tersebut pun sifatnya sementara. Perjanjian tersebut masih membutuhkan pengesahan serta penguatan, proses tersebut dinamakan ratifikasi.

\section{Analisis}

Dalam suatu realitas suatu hubungan, baik hubungan personal maupun interpersonal, nasional maupun internasional, memiliki beberapa keterkaitan dan ketergantungan satu sama lainnya. Keterkaitan tersebut memberikan kontribusi yang sangat kuat bagi hubungan pihak-pihak yang bersangkutan. Namun, ketika kita memahami suatu hubungan antar negara satu dengan lainnya yang diartikan sebagi hubungan internasional ini, hal-hal yang mempengaruhi baik dari segi positif maupun negatifnya masih cukup banyak. Entitas Globalisasi membuat negara-negara menjadi satu dan bergabung membentuk wadah organisasi yang mana tujuan kedepannya ialah agar dapat tercapainya suatu bentuk kerjasama regional maupun keamanan bersama.

Beberapa kontroversi terus menerpa hubungan Indonesia dengan Malaysia sebelum pemerintahan orde baru muncul. Seperti yang kita ketahui, pada saat era presiden Soekarno, politik "Ganyang Malaysia” yang dikeluarkan sebagai senjata untuk memberontak sekaligus menentang pembentukan persemakmuran Inggris, federasi Malaysia. Malaysia dinilai sebagai bentuk pengaruh imperialisme barat yang disebarkan oleh Inggris, dan kemudian, memberikan suatu ide konfrontasi yang bersifat radikal terhadap kebijakan luar negeri Indonesia yang dikeluarkan presiden Soekarno pada masa Orde Lama.

Hubungan Indonesia Malaysia yang pertama kali dikenal dalam konstelasi politik regional, diawali dengan konfrontasi Indonesia vs Malaysia. Persamaan rumpun (melayu), sejarah, letak geografis serta persamaan bahasa yang sama tidak menjadikan Indonesia dan Malaysia menjalin hubungan yang sangat baik dan berlangsung secara harmonis, bahkan hubungan Indonesia sangatlah buruk ketika itu. Perbedaan sejarah kolonialisasi membuat rezim Soekarno atas ketidakpuasan terbentuknya negara Malaysia pada dekade tahun 1960an. Penyebarluasan imperialisme barat yang dinilai Soekarno memberikan pengaruh negatif terhadap kelangsungan negaranegara Asia Tenggara akhirnya membentuk suatu persepsi dan hubungan yang kurang baik dengan Malaysia.

Pemulihan Hubungan IndonesiaMalaysia atas konfrontasi yang dibuat oleh Soekarno, diakhiri pada tahun 1967 dan sekaligus menggantikan posisi pemerintahan Soekarno yang jatuh karena pemberontakan G-30S/PKI, kemudian berganti menjadi pemerintahan Soeharto yang sekaligus merupakan awal mula dari pemerintahan Orde baru ini. Upaya menggalakkan pemulihan hubungan diplomatik Indonesia-Malaysia pada khususnya dan Indonesia-PBB pada umumnya dicerminkan melalui kembalinya Indonesia dalam keanggotaan PBB.

Akan tetapi, perjalanan hubungan diplomatik antarnegara bertetangga memang tidak selalu berjalan mulus dan lancar. Utamanya Indonesia belakangan ini gencar disinggung oleh klaim budaya melalui propaganda pariwisata Malaysia. Kemudian, isu Terorismeyang gencar dibicarakan. Malaysia dinilai sebagai bangsa yang sangat melecehkan Indonesia bahkan menginjak-injak harga diri Indonesia. Dari hal inilah terlihat bahwa hubungan yang terjalin antara IndonesiaMalaysia tidak berjalan secara harmonis 
dan tidak mencerminkan suatu hubungan timbal-balik dalam lingkup geografis yang dapat menghasilkan kerjasama dari sektor perekenomian maupun militer. Demikian juga halnya dengan perjanjian kerja antara Indonesia dan Malaysia, yang dapat dilihat dari MoU Indonesia-Malaysia.

$\begin{array}{cccr}\text { MoU } & \text { (Memorandum of } \\ \text { Understanding) } & \text { yang } & \text { merupakan } \\ \text { perbaikan dari } & \text { tahun } & 2006 \text { ini }\end{array}$
ditandatangani oleh Menteri Tenaga Kerja dan Transmigrasi Muhaimin Iskandar dan Menteri Sumber Manusia Malaysia, Datuk S Subramaniam di Bandung hari Senin pada tanggal 30 Mei 2011. Indonesia telah menghentikan pengiriman penata laksana rumah tangga ke Malaysia untuk sementara waktu sejak Juni 2009. Salah satu penyebabnya adanya kasus-kasus penyiksaan pekerja rumah tangga di Malaysia.

Mengenai isi MoU yang merupakan pembaruan dari MoU tahun 2006, Kepala Pusat Humas Kementerian Tenaga Kerja Suhartono menjelaskan mengenai masalah struktur gaji, berkaitan dengan libur satu hari bagi pekerja kecuali kesepatkaan akan diganti bila tetap bekerja, serta paspor akan dipegang oleh TKI itu sendiri.

Struktur gaji akan ditentukan dalam perjanjian kerja sebelum berangkat. Ada suatu perjanjian kerja antara pekerja dan majikan dari segi pembayaran dan pemotongannya. Untuk ketentuan minimum gaji, dalam Mou itu tidak disebutkan. MoU ini juga mengatur liburan pekerja rumah tangga, seperti berikut: "Mereka yang bekerja satu minggu diberikan satu hari kepada tenaga kerja Indonesia untuk liburan." Selama libur pekerja di sektor rumah tangga ini diperbolehkan keluar rumah. Begitu juga mengenai paspor yang akan diberikan kepada tenaga kerja.

Sejak moratorium dilakukan tahun 2009, perundingan baru MalaysiaIndonesia mengarah kepada pencabutan penghentian sementara tenaga kerja ke Malaysia. Sementara itu Direktur
Kerjasama Luar Negeri Kawasan Asia Pasifik dan Amerika Anjar Prihantoro, dikutip situs Badan Nasional Penempatan dan Perlindungan Tenaga Kerja Indonesia mengatakan bahwa penetapan biaya penempatan TKI ke Malaysia sekitar Rp.12 juta, di mana biaya yang harus ditanggung oleh pengguna di Malaysia sekitar Rp.7,6 juta sementara yang Rp.5 juta harus ditanggung oleh TKI seperti biaya kesehatan, paspor hingga tiket.

\section{PENUTUP \\ Kesimpulan}

Hubungan kedua negara harus dibangun dan dikembangkan dengan caracara yang lembut, damai, halus dan tidak menyinggung perasaan apalagi menyakiti hati, karena kita satu serumpun, satu saudara dan satu agama (mayoritas penduduk kedua negara Muslim), yang dimulai dari kepala pemerintahan, yang diikuti para menteri terutama kementerian luar negeri, dan duta besar sebagai ujung tombak, para diplomat, berbagai kekuatan sosial politik di parlemen Indonesia dan Malaysia, akademisi, media, NGO, masyarakat dan lain sebagainya. Terutama dalam pembuatan perjanjian-perjanjian pekerjaan, agar tidak ada pihak yang merasa dirugikan.

\section{Saran}

Perjanjian-perjanjian yang dibentuk oleh Indonesia dan Malaysia tidak boleh berat pada satu negara saja. Tetapi harus adil bagi kedua pihak yang membuat perjanjian. Agar hubungan antar kedua negara tetap terjaga, dan terjalin hubungan yang baik.

\section{DAFTAR PUSTAKA}

A, Hakim. (2005). "Intisari Kewarganegaraan untuk SMA”. Bandung: CV Pustaka

Budiardjo, Miriam. (1982). "Dasar-dasar Ilmu Politik”. Jakarta: PT. Gramedia 
Depdikbud. (2001). "Kamus Besar Bahasa Indonesia”. Jakarta: Balai Pustaka

Kaelan. (2003). "Pendidikan Pancasila”. Yogyakarta. Paradigma

Manan, Bagir. (2003). “Teori dan Politik Konstitusi”. FH UII Press

Muchson AR. (2000). "Dasar-dasar Pendidikan Moral, Jurusan Pancasila dan Kewarganegaraan”. FIS UNY

Moctar Kusumaatmadja, Etti R. Agoes. (2001). "Pengantar Hukum Internasional”. Bandung. PT. Alumni.
Retno Listyarti, Setiadi. (2008). "Pendidikan Kewarganegaraan, untuk SMK dan MAK Kelas XI”. Jakarta: Erlangga.

Setia R. Subekti. (2002). "Hukum Perjanjian, cet. 19”. Jakarta: Intermasa.

Soehardi. (2005). "Kamus Populer Kepolisian”. Jakarta: Koperasi

Wira Raharja Suprapto, dkk. (2005). "Kewarganegaraan untuk SMA kelas 2". Jakarta: Bumi Aksara

Surbakti, Ramlan. (1992). "Memahami Ilmu Politik”. Jakarta: Grasindo 